\title{
Nursing Genetics and Genomics Education in Indonesia: Philosophy and Ethics Study (a Hermeneutics Approach)
}

\author{
Karolus Yosef Woitila Wangi ${ }^{1}$, Innama Sakinah ${ }^{2}$, Dewi Andariya Ningsih ${ }^{3}$, \\ Noviana Vanawati ${ }^{4}$, Dian Adiningsih ${ }^{5}$, and Erna Juliana Simatupang ${ }^{1}$ \\ ${ }^{1}$ Nursing Department, Tarumanagara School of Health Sciences, Jakarta, Indonesia \\ ${ }^{2}$ Midwifery Department, Faletehan University, Banten, Indonesia \\ ${ }^{3}$ Faculty of Health, Ibrahimy University, Jawa Timur, Indonesia \\ ${ }^{4}$ Doctoral Student of Biology, Institute of Technology Bandung, Jawa Barat, Indonesia \\ ${ }^{5}$ Fundamental Nursing Department, Faculty of Nursing, Padjadjaran University, Jawa Barat, \\ Indonesia
}

ORCID:

Karolus Yosef Woitila Wangi: https://orcid.org/0000-0002-4160-6063

\section{Abstract}

Corresponding Author:

Karolus Yosef Woitila Wangi

oluzwangi23@gmail.com

Published: 15 March 2021

Publishing services provided by

Knowledge E

(c) Karolus Yosef Woitila Wangi et al. This article is distributed under the terms of the

Commons Attribution License,

which permits unrestricted use and redistribution provided that the original author and source are credited.

Selection and Peer-review under the responsibility of the IVCN Conference Committee.
This study was conducted to provide a philosophical and ethical description of the development of genetics and genomics nursing science and the importance of its incorporation into nursing education in Indonesia. Researchers have adopted five of the seven steps of the Heideggerian hermeneutics. All data has been obtained from literature research. The qualitative analysis of secondary data has applied the data analysis. The Coherence theory of truth criteria has been applied to maintain the consistency of scientific truth. The consistent statement system has used the principle of logic as a guide to interpreting the facts and opinions of others adequately. Nursing genetics and genomics is an ethical, philosophical product of nursing science development and a new scope of science as an adaptation to global health issues. The areas of science in nursing need to be developed further by placing genetics and genomics issues that can be adapted into the curriculum of the nursing higher education curriculum in Indonesia.

Keywords: Education; Ethics; Genetics; Genomics; Philosophy

The concept of the disease can be seen from the genetic aspect. The development of global science has grown in the study of molecular level. Molecular medical science is becoming a global trend towards the concept of precision medicine [1]. It becomes a reference for each country to adapt. Nursing as a profession has developed its science and practice by accommodating genetic and genomic issues in the care of health services globally. Various studies have been conducted in developed countries 
to improve genetic and genetic nursing science both in the clinical and theoreticalpractical level by looking at its urgency. One study that has been conducted in America found out that most clinical nurse practitioners assumed genetics as an essential for nursing practice [2]. Genetic diseases are caused by changes or mutations in the nucleotide sequence in human DNA (deoxyribonucleic acid). The emergence of genetic diseases can be caused by both parent-derived and nucleotide-sequential changes due to environmental factors [3].

Basic Health Research Data of the Health Research and Development Agency of the Ministry of Health of the Republic of Indonesia 2013 shows that asthma, diabetes mellitus, and coronary heart disease, are classified into genetic diseases with the highest prevalence of patients compared to other genetic diseases in Indonesia. Asthma is one of the most severe allergic diseases and has the most complex triggering factors because it can be genetically derived from one family member or caused by environmental factors [4]. The number of asthma prevalence in Indonesia has been increased since 2007 from $3.5 \%$ to $4.5 \%$ in 2013 or about 11 million people, followed by diabetes in 2007 from $1.1 \%$ to $2.3 \%$ in 2013 or about 5 million people, and patients with coronary heart 2013 as much as $1.5 \%$ or about 3.7 million people [5]. This data shows the highest number of people which caused by genetic diseases.

This phenomenon needs to be taken seriously. The role of molecular medicine has grown tremendously since The Human Genome Project, which can be revealed the mapping of necessary human genetic information so it can be used for medicinal purposes. The advancement of science and technology has prompted scientists in the global nursing field to conduct study and expansion of their respective scientific branches as urgency. The healthcare environment is rapidly changing and has resulted in the expansion of health information that impacts on people's welfare, patients' safety, and cost control. This phenomenon poses its challenges for health experts including nursing for how to introduce new relevant competencies, with clinically relevant knowledge into patient care [6].

Indonesia as one of the developing countries and part of the global world is required to adapt to the issue. The global issue must be accepted as a collective agreement for the advancement of national science and nursing practice which has a major impact on the improvement of quality in the following patient health care. But is Indonesian nursing prepared in addressing and translating global issues in genetics and genomics into the profession? This study was conducted with the general purpose of providing a philosophical and ethical description about the development of nursing genetics and genomic and its urgency to be translated into nursing education particularly in Indonesia. 


\section{Methods}

The method of this research is an explorative method. The method is applied when the knowledge of a symptom that will be investigated is still very less or not even exist. [7]. Then, for the type of the research is done by literature study which means a critical review of the materials that associated with the issues that raised in the study and then detailed in a systematic and analyzed deductively [8]. All data that has been used in the literature study is secondary data that has been obtained from official documents, books, and the results of research in the form of reports [7]. The approach that has been adopted in this research is hermeneutics approach that is the process of content review and the objective purpose of text to its deepest and latent meaning [9]. A method will use a hermeneutic approach if one aims to analyze the theme [10]. Researchers have adopted five of the seven steps of the Heideggerian hermeneutics in Nature approach in the data collection phase: 1) examination of the text as a whole; 2 ) summarizes parts of the text and identifies the categories; 3 ) analyze the text by category in the second step; 4) identify rational themes in texts; and 5) produce a constitutive pattern in the text [11]

The data analysis has been conducted on literature data using qualitative analysis technique that is an analysis which describes with words on the findings [12]. Then, to ensure that the results of the data analysis get the scientific truth, it has been used the coherence theory of truth, an approach that has rationale which a truth can be accepted and generally accepted if it refers to a system of consistent statements on a previous proposition or others preposition [13]. The system of consistent statements that has been used is directed to the principle of logic which aims to help to interpret the facts or opinions of others adequately [14].

\section{Results and Discussion}

\subsection{Philosophy of Science in Nursing Genetics and Genomics Pro- cess}

The high level of curiosity and the experience in solving a problem encourage and shape the human mindset to develop new knowledge. Knowledge is defined as facts or information which considered correct that based on the thoughts that involve empirical testing (beliefs about the phenomenon which observed directly) or by another process of thinking, such as logical reasoning or problem-solving [15]. Furthermore, science is the way to describe symptoms scientifically and relationally [16]. Science has been 
developed rapidly along with the progress of human civilization. The technology in the health sector has been affected. Theoretically, the natures of scientific knowledge are descriptive, explanatory, predictive, methodical, verification, systematic, and objective. [16]. These qualities justify that knowledge needs to be tested scientifically and strictly to be recognized and accepted by human civilization. This test is done to deliver new knowledge that more specifically.

One of them is the science of nursing genetics and genomics. The tendency of human's big curiosity has led this field to grow quite rapidly. With the reference of the operational definition of science which aims to achieve the scientific truth about certain objects that has been obtained through particular approaches, methods, and systems [17], then nursing genetics and genomics has been developed by utilizing such methods. Specific theories of nursing have been acculturated to distinguish them from other health professions. This process proves that nursing genetics and genomics has deserved to be called a new branch of nursing discipline. Florence Nightingale is one of the nurses who has built the theoretical foundation for nursing profession by developing and delivering the philosophy about healthy relationship with nursing and has set limits of nursing practice to distinguish between medical service and nursing care service [18].

Although the subject of the study between nursing and medical science is equally human-focused which suggested that there has been overlapping of authority between physicians and nurses in a "gray area" but this is not the case. In its development, Handerson (1964) has made it clear that the definition of nursing includes explicitly an attempt to improve the patient's condition and quality of life and increase the scope of nursing science concepts which more focused on how patients perceive the extent to face the situation they experienced when facing a disease and get treatment from a doctor [19]. In the concept of the law of simple physics, it can be likened that the invasion of disease or patient's problem is the action which given to the patient who then responded by the patient as a reaction. The focus of the holistic nursing study lies on the patient's reaction to disease or problems. The American Nursing Association [20]looks at the patient's reaction as a human response to actual and potential health problems that need to be addressed (21)]. Problems in genetic diseases are actual problems and potential problems that need to be reviewed so it will not cause a high risk that threaten patient's health, massively.

"Free will": Ethics Concept as The Foundation of Nursing Genetics and Genomics Development

The element of value for human beings is a parameter for doing an action. That right can be studied or reviewed in ethics as philosophical discourse. Ethics can be 
interpreted as a way of acting which in descriptive approach has the meaning of depiction of moral behavior whether it is good or bad action [22]. Ethics do not only regulate the moral obligation of human beings against others, but it is also a moral obligation for themselves. One of the obligations is the obligation to demand knowledge which is a means to overcome various problems in human life during civilization [23]. This obligation requires moral responsibility for every human being with all the available abilities to develop their potential and a lifetime learning to discover new things, new ways, and new methods in science so that civilization can be enjoyed more appropriately. That concept can be adapted specially in the world of health on genetics and genomics in fact has been greatly evolved with new technologies in improving human lives.

The moral obligation of the health profession deals specifically with the obligations of the nurse. Nurses must follow the development of science and technology of nursing or health continuously [24]. That obligation has given a compulsory that tends to "enforce" every nurse to do so. Nurses must always develop themselves in the field of science for the advancement of the profession. It is not limited to nursing academic education, but more advanced, for instance, joining the training with specific competencies in the field of genetics and genomics. Theoretically, this is arranged because nurses have an ethical obligation to gain science and following the development of global nursing science by considering the latest health technology development to improve their professionalism [25]. These requirements must be carried out with the utmost effort for a better human's health and to increase the existence of nurses in the roles of global health.

Technically, more specifically, these requirements are arranged in the ethics of the health profession. There is a set of values to regulate the life of a circle of professional members who are then called professional codes of ethics. This code contains the obligations that need to be performed by its members. In the Indonesian National Code of Nursing Ethics, one of the obligations of nurses is to apply knowledge by the needs of clients, families, and society [26]. This obligation has tied the members of the nursing profession as a consequence of the vow of profession which has been vowed before. Obligations which of course must be utilized with good intentions by the progress of scientific progress. The development of personal competence of nurses in the genetic and genomic fields should be done consciously with a positive end goal to improve people's lives and improve the quality of human's life. Although scientific and technological progress is scientifically ambivalent, it has both positive and negative consequences [27]. 
This matter needs to be taken seriously considering that humans have a fundamental right to freedom of psychology, which means a human's freedom to develop and direct his life. This ability concerns the desire or even as his trademark. The freedom of psychology is often called "free will." This freedom is closely related to the fact that humans are creatures of the ratio so that they can think before acting by making a consideration [27]. This freedom certainly needs to be adopted well and responsibly. The development of nursing science in the field of genetics and genomics should be seen and understood as freedom to develop science with a good purpose and provide the highest utility for nurse practice in running nursing care to the patients.

Although it is clear that The Human Genome Project has provided great ethical implications as it provides a great opportunity for scientists to manipulate human's life in many ways, an international level, the United Nations Educational Scientific and Cultural Organization (UNESCO) through the International Bioethics Committee (IBC) have studied ethics in science and technology especially in genetics and genomics by issuing international guidelines, namely Universal Declaration on the [28], [27]. This is an achievement that the international world is paying great attention to, in the field of science. With these guidelines, scientists nurse has clear guidelines in implementing their "free will" scientifically, especially in genetics and genomics without fear of ethical violations. This has implicitly implemented a new kind of ethics that focuses on human's obligations and responsibilities to maintain the unity of the conditions of a human's life in the future [29]. With this, the nurse as the technologist has ethical assurance in developing the nursing genetics and genomics as a positive implication of "free will" in accordance with the mandate of the profession.

\subsection{Nursing Genetics and Genomics as a Part of Nursing Science}

Genetic and genomic nursing has been a new study in the field of nursing science as one of the philosophical products through the results of research and the development of previous nursing science. This is based on the trend of adaptation to the science of molecular biology that has found genetics as the unit of matter for determining human's nature. Genetics is a field of science that studies the inheritance of traits or variations [3]. Genomics is a field that studies the study of all the relationships of human's genes together, including their interaction with each other, the environment, and the influence of psychosocial and cultural factors on such interactions [6]. The Human Genome Project has laid the groundwork for major advancements in this field. The ability to understand the role of genetics in health and disease is a remarkable step towards better prevention, 
care and healing for common illnesses and health problems [20]Practically, this field has been an important study to address issues surrounding the inheritance of human nature and the emergence of several diseases. The human genetics point of view can be used to answer basic questions about how a disease can be experienced by humans and intervene it precisely. This has certainly changed our paradigm about a disease and how humans deal with it.

This paradigm has changed the way health professionals view to translate it into clinical practice. Nurses have a challenge for that. The scope of nursing science has been expanded with philosophical and ethical propositions so that the development of the discipline can maintain the existence of the useful nursing practice. This has been conducted through various studies and mixed methods researches to produce new disciplines namely nursing genetics and genomics. Some areas of science such as genetics, biology, behavior, social, and medical as well as other related fields provide a framework for understanding, applying, and evaluating genetics nursing practice [20]

. In 2006, the National Human Genome Research Institute and the National Cancer Institute have been collaborated to form the Genetics/Genomics Nursing Competency Initiative $(\mathrm{GGNCl})$ with some rationale one of which is that all aspects of the health sequence have been influenced by genomics development, so clinical applications need to use genomics to identify individuals at risk, screen and diagnose diseases, clarify the prognosis, and optimize drug therapy to maximize therapeutic benefits and minimize the outcome of adverse events [2]. This has been an important initiation undertaken as the basis for the establishment of the competence of genetic and genomic nursing practice.

Until now, nursing has undergone dramatic changes in response to the needs of society and its effects so that nursing practice develops in aspects of biotechnology that affect health care for example, DNA-based vaccines that has begun to replace conventional vaccines, so nurses need to expand basic knowledge and technical skills to meet new patient's needs [21]. In traditional practice, nursing genetics have involved the care of people with single genes and chromosomal disorders such as cystic fibrosis, Huntington disease, and down syndrome. However, single gene disorders have been modified by other genes and environments that result in the expansion of nursing studies to incorporate genomics aspects by involving health problems associated with many genes in the human genome, including interactions with each other and the environment, as well as the influence of psychosocial and cultural factors. Thus in a broader context, the recipient of nursing genetics practice may be an individual, family, community, or population but not limited to genetic changes that affect the abnormalities 
of embryonic development and congenital anomalies as well as at-risk couples who have children with genetic disorders [20].

\subsection{The Translation of Nursing Genetics and Genomics Education in Indonesia}

Education in nursing is a period time taken by a person to become a professional nurse. There are various levels of nursing education that is diploma, bachelor, professional education, specialist education, master, and doctoral. The nursing higher education system is essential in the development of professional nursing, nursing technology development, professional coaching and continuing nursing education [30]. The fact in genetics and genomics show the unavailability of the adequated education system in the field of genetics and genomics in Indonesia nursing education. Nursing education should continue to adapt to the needs of the community and refer to an internationally accepted standard. Globalization is a process of a global community order and does not recognize territorial boundaries. Globalization raises the idea that has been offered to be followed by a nation then mutually agreed upon and it becomes a common guideline for nations around the world. [30]. Indonesia as one of the countries with a large number of nurses needs to see the global benchmark as the national standard, although the global trend of health is both an opportunity and a challenge for the nursing profession. This situation requires the involvement of the nursing profession to be more active thus increasing the need for the availability of professional nurses and having special abilities [31] in this case the ability in genetics and genomics.

As mentioned earlier, The Human Genome Project has led to major changes in clinical practice, research, education, and policy. Mastering this information is necessary for the nurse because the information about genomics information ultimately becomes the basic information in health care [6]. This real phenomenon must be seen as a new revolution in the health sector with a massive impact, especially for the global health paradigm. Nursing as a process is very dynamic and changes and develops characteristics by the demands of the profession and the needs of society. This means that nurses are expected to meet global standards in providing nursing care services. More specifically in the field of the profession, the development of global science in the field of nursing genetics and genomics has been continuously developed. In recognition of progress in genomics, nursing has increased emphasis on genomics integration into professional practice and educational standards. Incorporating genomics into nursing practice may begin with changes in the undergraduate nursing curriculum [32]. Some 
contents of nursing genetics and genomics undergraduate curriculum [32], that have been processed and adapted to local needs so as to illustrate some of the genetic and genomic-related issues that are sources of information, topics, and adaptations that can be translated into the nursing undergraduate curriculum education in Indonesia. Table 1 explains some potential health problems that can be seen from both genetic and genomic perspectives. The network of nursing education institutions in applying genomics principles for nursing is a critical element in maintaining nursing education to produce nurses who can apply essential genomics knowledge. There is an urgent global need to offer genomics inaccessible and effective education in nursing practice to optimize health outcomes regardless of geographic location [33]. Within the scope of nursing education curriculum, renewal needs to be done immediately. This hope becomes a common goal so that national nursing education can compete internationally and answer the needs of society globally. Within the national scope, periodic review of nursing practice in various fields, it is important to follow the latest health developments and support the improvement of health status [34]. It is a guarantee that change can be implemented according to global demands. The role of professional organizations is expected in addressing it. To support the implementation of nursing genetics and genomics practices that have national standards, genetics and genomics development of nursing field comprehensively needs to be realized by forming a new collegium in accordance with Article 45 of Law No. 38 of 2013 on Nursing, namely nursing genetics and genomics collegium.

But not only that, the development of genetic and genomic nursing that begins in the field of nursing education is a significant first step as a basis for translating the nursing practice in question. Therefore, it is necessary to improve the oriented nursing education system to the needs of the community as well as primary health care with a solid foundation which covering scientific insight, educational orientation, and the concept of nursing education framework that focuses on the mastery of nursing science [30]. The national nursing organization, in this case, the Indonesian National Nurses Association has a strong enough share in this matter, as regulated in Law Number 38 the Year 2013 on Nursing Article 41 paragraph which affirms that professional organizations aim to improve and develop knowledge and nursing skills. It has logical consequences for the development of nursing genetics and genomics in Indonesia. Due to the dynamic scope of nursing practices that are responsive to changes in health needs, knowledge development, and technology [34], it is hoped that with great enthusiasm this challenge can become a reference for the development of nursing genetics and genomics in Indonesia. 
TABLE 1: Genetics and Genomics Issues in the Field of Nursing Sciences

\begin{tabular}{|c|c|}
\hline Area of Study & Issues related to Genetics and Genomics \\
\hline $\begin{array}{l}\text { Basic Sciences in } \\
\text { Nursing }\end{array}$ & $\begin{array}{l}\text { Biology, anatomy, physiology, pathophysiology so as to provide a basic } \\
\text { understanding of DNA concepts including polymorphism, penetration, } \\
\text { epigenetics, frameshit mutations, and inheritance modes }\end{array}$ \\
\hline Anamnesis in Nursing & $\begin{array}{l}\text { Health assessments can introduce the concept of collecting patient } \\
\text { history, constructing a three-generation genealogy, explanation of } \\
\text { genetic testing and screening, basic genetic terminology (such as } \\
\text { genotype, phenotype, and allelic expression) }\end{array}$ \\
\hline $\begin{array}{l}\text { Ethics, laws, and Social } \\
\text { implication }\end{array}$ & $\begin{array}{l}\text { Ethical, legal, and social implications on genetic and test conditions as } \\
\text { well as genetic screening include prenatal screening }\end{array}$ \\
\hline $\begin{array}{l}\text { Pharmacology in } \\
\text { Nursing }\end{array}$ & $\begin{array}{l}\text { The introduction of pharmacogenetic and pharmacogenomic concepts } \\
\text { includes aspects of genetic differences that affect drug metabolism } \\
\text { personally }\end{array}$ \\
\hline $\begin{array}{l}\text { Medical surgery } \\
\text { nursing }\end{array}$ & $\begin{array}{l}\text { Discussion of the respiratory system that focuses on the genetic } \\
\text { conditions of autosomal cystic fibrosis and gene therapy; oncology } \\
\text { discussions focus on BRCA } 1 \text { / BRCA } 2 \text { and PBLA mutations and } \\
\text { multifactorial complexes on polygenetic conditions such as diabetes } \\
\text { mellitus }\end{array}$ \\
\hline $\begin{array}{l}\text { Maternal and child } \\
\text { nursing \& Midwifery }\end{array}$ & $\begin{array}{l}\text { Patterns attached to breast cancer or discussion of down syndrome } \\
\text { trisomy } 21 \text { and the importance of prenatal testing and patient education, } \\
\text { including discussion of dysmorphology, newborn testing for PKU } \\
\text { (Phenylketonuria), sickle-cell anemia, familial hypercholesterolemia, } \\
\text { Marfan Syndrome and Alzheimer's Disease }\end{array}$ \\
\hline Mental health nursing & $\begin{array}{l}\text { Bipolar disorder, schizophrenia, familial retinoblastoma, familial } \\
\text { adenomatous polyposis, twohit concept exploration in cancer theory and } \\
\text { pharmacogenemic and environmental (ecogenetic) implications }\end{array}$ \\
\hline
\end{tabular}

\section{Conclusion}

Genetic and genomic nursing was a part of nursing science that has been developed based on a process in the scientific method. The nurses needs to use the fundamental right of "free will" responsibly as an ethical obligation to develop nursing genetics and genomics. The National Human Genome Research Institute and National Cancer Institute have been collaborated to establish the Genetics/Genomics Nursing Competency Initiative (GGNCl) as a global reference with one of the premises that all aspects of the health chain has been influenced by genomics development so that can be adopted in clinical nursing practice to identify individuals at risk, screen and diagnose diseases, clarify the prognosis, and optimize drug therapy to maximize benefits and minimize side effects. In this case, the recipient of nursing genetics and genomics practice is a person, family, community, or population. Nursing education in Indonesia should accommodate the growing issues in international nursing that currently has trended in the field of genetics and genomics as a logical consequence of technological progress and global health needs. There has been a pressing need globally to include genetics 
and genomics issues in nursing education in many countries regardless of differences in educational standards and geographic conditions.

\section{Funding}

All authors declare no funding for this research.

\section{Acknowledgement}

The authors would like to thank their colleague for their contribution and support to the research. They are also thankful to all the reviewers who gave their valuable inputs to the manuscript and helped in completing the paper.

\section{Conflict of Interest}

The author declared no potential conflicts of interest with respect to the research, authorship, and/or publication of this article.

\section{References}

[1] Hudson, R. (2016). Precision Medicine. Retrieved from https://www.nature.com/ articles/537S49a.pdf.

[2] Calzone, K. A., et al. (2012). Survey of Nursing Integration of Genomics into Nursing Practice. J Nurs Scholarsh., vol. 44, issue 4, pp. 428-36.

[3] Reece, J. B., et al. (2013). Campbell Biology (10 ${ }^{\text {th }}$ ed.). USA: Pearson Publisher, Inc.

[4] Bijanzadeh, M., Mahesh, P. and Ramachandra, N. (2011). An Understanding of the Genetic Basis of Asthma. Indian Journal of Medical Research., vol. 133, issue 2, pp. 149-61.

[5] Riskesdas. Riset kesehatan dasar (Riskesdas) 2013. Jakarta Badan Penelitian dan Pengembangan Kesehatan.

[6] Jenkins, J., et al. (2015). Methods of Genomic Competency Integration in Practice. J Nurs Scholarsh., vol. 47, issue 3, pp. 200-10.

[7] Soekanto. (2012). Pengantar Penelitian Hukum. Jakarta: UNiversitas Indonesia.

[8] Nasution, B. J. (2008). Metode Penelitian IImu Hukum. Bandung: Mandar Maju.

[9] Sudarto. (2002). Metodologi Penelitian Filsafat. Jakarta: PT. Raja Grafindo Persada. 
[10] Ortiz, M. R. (2009). Hermeneutics and Nursing Research: History, Processes, and Exemplar. South Online J Nurs Res., vol. 9, issue 1, p. 6.

[11] Young, P. and Diekelmann, N. (2002). Learning io Lecture: Exploring the Skills, Strategies, and Practices of New Teachers in Nursing Education. Journal of Nursing Education., vol. 41, issue 9, pp. 405-12.

[12] Salim, H. S. and Nurbani, E. S. (2013). Penerapan Teori Hukum Pada Penelitian Tesis Dan Disertasi. Jakarta: Raja Graf Persada.

[13] Marzuki, P. M. (2014). Penelitian Hukum. Jakarta: Kencana Prenada Media Gr.

[14] Sumaryono, E. (1999). Dasar-Dasar Logika. Yogyakarta: Kanisius.

[15] Basford, L. and Slevin, O. (2006). Teori dan Praktik Keperawatan: Pendekatan Integral pada Asuhan Pasien. Jakarta: EGC.

[16] Lubis, A. Y. and Adian, D. G. (2011). Pengantar Filsafat IImu Pengetahuan. Depok: Penerbit Koekoesan.

[17] Suhartono. (2007). Dasar-Dasar Filsafat. Yogyakarta: Arr-Ruzz Media.

[18] Soemowinoto, S. (2010). Pengantar Filsafat IImu Keperawatan Suatu Epistemologi. Jakarta Salemba Med.

[19] Alligood, M. R. (2017). Pakar Teori Keperawatan dan Karya Mereka (8 ${ }^{\text {th }}$ ed.). Singapore: Elsevier.

[20] American Nursing Association. (2011). Genetics/Genomics Nursing: Scope and Standards of Practice. Retrieved from https://www.nursingworld.org/ ${ }^{\sim 4 a f 102 /}$ globalassets/docs/ana/ethics/ebook_genetics--genomics-nursing-scp--stds-ofpractice.pdf.

[21] Kozier, B., et al. (2019). Buku Ajar Fundamental Keperawatan 1. Jakarta: EGC.

[22] Wulan, K. and Hastuti, M. (2011). Pengantar Etika Keperawatan-Panduan Lengkap Menjadi Perawat Profesional Berwawasan Etis. Jakarta: PT Prestasi Pustakaraya.

[23] Salam, B. (2000). Etika Individual Pola Dasar Filsafat Moral. Jakarta: Rineka Cipta.

[24] Suhaemi, M. E. (2004). Etika Keperawatan: Aplikasi Pada Praktik. Jakarta EGC.

[25] Hasyim, M. and Prasetyo, J. (2012). Etika Keperawatan. Yogyakarta: Penerbit Bangkit.

[26] Haryono, R. (2013). Etika Keperawatan dengan Pendekatan Praktis. Yogjakarta: Gosyen Publishing.

[27] Bertens, K. (2013). Etika. Yogyakarta: Kanisius.

[28] Hodson, R. (2016). Precision Medicine (vol. 537). England: Nature, p. 49.

[29] Suseno, F. M. (2006). Etika Abad ke-20. Yogjakarta: Kanisius.

[30] Dermawan, D. (2013). Pengantar Keperawatan Profesional. Jogjakarta: Gosyen Publ. 
[31] Simamora, N. R. H. and Kep, M. (2009). Buku Ajar Pendidikan Dalam Keperawatan. Jakarta: EGC.

[32] Sharoff, L. (2015). Genetics and Genomics Integration into Undergraduate Nursing Education. J Nurs Educ Pract., vol. 5, issue 4, pp. 13-8.

[33] Williamson, G. R. and Whittaker, A. (2011). Succeeding in Research Project Plans and Literature Reviews for Nursing Students. Sage Publishing.

[34] Indonesia AIPN. (2016). Kurikulum Inti Pendidikan Ners 2015. Jakarta: AIPNI. 